\title{
Sacred source of legitimation of the Malvinas war heroes
}

\author{
Keywords: Malvinas war; Darwin cemetery; Desaparecidos; \\ Human rights
}

\section{Introduction}

On April 2, 1982, the Argentine dictatorship (the self-appointed "Process of National Reorganization,") decided to recover the Malvinas Islands for the country. This led to a war between Argentina and Great Britain that ended on June $14^{\text {th }}$ of the same year with the defeat of the Argentine armed forces, leaving a death toll of 649 Argentine soldiers ${ }^{1}$.

Of the 436 victims, 237 are buried in Darwin cemetery on Soledad Island; 230 are in individual graves and the remaining seven are in mass graves. Of the 230 graves, 123 have stones that read" "Soldier known only to God ${ }^{2}$." Those who are not buried in the cemetery include the 323 Argentines who sank aboard the ARA General Belgrano cruiser ${ }^{3}$, several others who sank aboard other ships, a number of pilots whose planes were shot down and a handful whose bodies were returned for burial on the mainland ${ }^{4}$.

The Malvinas War was declared under a dictatorship that had begun in 1976. The administration was based on the systematic violation of human rights, and the repression mainly involved the detention of thousands of people in clandestine detention centers. Prisoners were subjected to interrogation and torture; the vast majority was later murdered and their bodies disappeared ${ }^{5}$. Similarly, the dictatorship imposed silence about the war after its defeat and Argentine society

${ }^{1}$ In this work, we refer to this episode as the Malvinas War (not the Falkland Islands War) since the relatives of the fallen Argentines refer to in this way. At the government level in Argentina, the Foreign Ministry tends to refer to it as the "Southern Atlantic Conflict," since the word "war" has very specific connotations in international law, with its own requirements and consequences. On the other hand, the conflict extended beyond the Malvinas Islands to the South Georgia and South Sandwich islands and the surrounding seas (data provided by Guillermo R. Rossi, minister plenipotentiary, Malvinas and Southern Atlantic Department, Argentine Ministry of Foreign Relations, International Trade and Worship).

${ }^{2}$ As during the first six months of the post-war the Argentine government did not take care of bringing the fallen to mainland Argentina, the English proceeded to exhume the remains of the Argentine soldiers in each of the battlefields and concentrated them in the cemetery located in Darwin, Isla Soledad. The physical identification of the soldiers and their final transfer to this cemetery was conducted by the British Colonel Geoffrey Cardozo, who systematized all the information about the activities carried out regarding the handling of the bodies. As not all the Argentine soldiers had the identification medal, those who did not have any identifying element were buried in tombs with the legend "Argentine soldier only known by God".

${ }^{3}$ On May 2, 1982, the ARA General Belgrano cruiser was sunk after an attack by a British nuclear submarine, the HMS Conqueror, killing 323 men aboard (Bonzo, 1992). Argentine society reacted with anger to the episode, as the attack occurred outside the war area established by the British government around the islands. For more on the way in which active, retired and discharged navy servicemen signified this episode, see Guber, 2008.

${ }^{4}$ In the case of the ARA General Belgrano cruiser, some of the bodies were recovered and returned to the families. These soldiers are buried in private cemeteries.

${ }^{5}$ For an in-depth examination on the question of death in the case of the desaparecidos, see Catela (2001) and Panizo (2011).
Volume 3 Issue I - 2018

\author{
Laura Marina Panizo \\ $\mathrm{PhD}$ in Social Anthropology, Universidad de Buenos Aires, \\ Argentina
}

Correspondence: Laura Marina Panizo, PhD in Social Anthropology, Universidad de Buenos Aires, Argentina, Email panizo@gmail.com

Received: June 29, 2017 | Published: January 08, 2018

came to identify both the war and the islands with the military government, producing an anti-Malvinas sentiment in the war's aftermath. ${ }^{1}$ In this regard, the Argentine government was blamed not only for the torture and death of thousands of desaparecidos, but also for the death of the young fallen soldiers; as in the case of the disappeared, the dictatorship provided no information on the whereabouts or the cause of death of the young men who lost their lives during the war ${ }^{6}$.

In spite of the fact that the State provided almost no information to the relatives of the fallen, it did handle the deaths of the soldiers differently from those of the desaparecidos, declaring those disappeared during wartime as officially dead a few months after the war's end. ${ }^{2,7}$ Thus, as the terrorist state handled the death of the victims of repression by denying and hiding what had happened to them, disappearance was initially legitimized as a category referring to both the living and the dead. When it came to the desaparecidos, different human rights organizations were founded with "antirepression formulations and demands, ${ }^{3}$ during the dictatorship; these groups began to insist on truth and justice during the dictatorship and continued with this demand after the return to democracy. The humanrights organizations organized by and for families of the disappeared include "Familiares de Desaparecidos y Detenidos por Razones Políticas", "Asociación Madres de Plaza de Mayo, Madres de Plaza de Mayo-Línea Fundadora", "Abuelas de Plaza de Mayo", "HIJOS (Hijos e Hijas por la Identidad y la Justicia contra el Olvido y el Silencio) and "HER-MANOS"(Hermanos de Desaparecidos por la Verdad y Justicia). Within the basic goals of these groups, a humanitarian narrative and the concept of the innocent victim predominated in the discourse of protest. Thus, the common bond of these groups was initially the search for the desaparecidos and the protest against their disappearance.

\section{Although the different actors interpreted what occurred and shaped}

${ }^{6}$ The father of Miguel Ángel Jiménez, a pilot whose plane was shot down during the war, founded the Comisión Nacional de Padres y Familiares de Combatientes Desaparecidos en Malvinas (the National Commission for Parents and Family Members of Soldiers Disappeared in Malvinas) in 1982. The goal of the commission was to obtain information from the State on how the soldiers had died (Guber, 2004:51; Lorenz, 2006:127). Although this initiative is emphasized in academic literature on the Malvinas War, the commission appears to have simply fizzled out a few years after its founding. ${ }^{7}$ The greatest number of those disappeared in action are the victims of the sinking of the ARA General Belgrano cruiser (Guber, 2004:51). 
the protests in different ways, all of the entities shared the principles of truth and justice. In this regard, the feature of the human rights entities is that they provided political support to Argentina's current president, Cristina Fernández de Kirchner (and had previously supported her deceased husband, Nestor Kirchner), because of the prominent role of human rights in both Kirchner administrations. Just as human rights organizations were formed, shortly after the end of the Malvinas War different non-governmental organizations were founded by both civilians and veterans. The goal of these organizations was to create spaces for mutual assistance among those who had shared the experience of war or, in the words of Rosana Guber, "in the claim for Argentina's territorial sovereignty over the Malvinas and South Atlantic Islands, in bearing witness to the war and in the memory of the conflict and the deceased," Although some family members collaborate or currently participate in the organizations of former soldiers or other groups associated with the war, the only official commission for families that has existed since the end of the war is the group Familiares de Caídos en Malvinas e Islas del Atlántico Sur. Unlike the other organizations mentioned above, Familiares de Malvinas is the only institution that brings together the family members without making demands or protesting against the federal government. Instead, Familiares de Malvinas aimsto publicly honor loved ones who died in the war, reaffirming Argentina's sovereign rights over the Malvinas Islands and promoting activities that reaffirm, in the group's words, the "concept of Argentinity," and "consolidate the cultural, spiritual and social values that characterize the Argentine people." Under the leadership of Héctor Cisneros as the group's president, Familiares de Malvinas maintained a critical attitude towards the administrations of both of the Kirchners. However, during the past year, the group has been led by Delmira de Cao and since then, relatives of the deceased have recognized Cristina Kirchner's commitment to the Malvinas cause on several occasions. Another difference between Familiares and the human rights organizations is that Catholicism plays a fundamental role in the ritual practices of most of the Malvinas families. In this regard, in this work I will examine how the family members who belong to this organization have dealt and continue to deal with the question of death. More specifically, we will see how family members attribute meaning to their losses within an interpretative framework in which the Virgen de Luján appears as their main identity symbol. ${ }^{8}$

\section{A framework for death}

Death in war produces a break, a rupture in the usual ways of dealing with death. Thus the families of the soldiers sent to Malvinas had to adapt to these changes in order to get through these extraordinary losses, creatively reworking the conventional models for understanding death. In this way, our interlocutors constructed an interpretative symbolic frame work to understand their suffering, borrowing symbols from Argentina's history, both recent and past. I will make reference to this interpretative symbolic framework or interpretative framework in order to refer to the model of interpretation of the group which, by selecting symbols and a particular ideology, ${ }^{9}$

${ }^{8}$ This work is the result of an anthropological research carried out between 2005 and 2013, where field work was carried out with participant observation and multiple interviews with family members of the "Family Commission of Fallen in Malvinas and South Atlantic Islands".

${ }^{9}$ According to the Clifford Geertz, the symbol is understood as any "object, act, event, quality, or relation," which serves as a vehicle of conception. ${ }^{9}$ At the same time, I believe that multiple meanings are consolidated within symbols, which neutralize ambiguous and contradictory ideas. ${ }^{10}$ Similarly, I take Geertz's contributions to understand ideology as a symbolic source of signification, which arises as a response to states of tension to "to render otherwise incomprehensible social situations meaningful,".? orients the way in which family members attribute meaning to death in the context of war.

The concept of frame analysis, introduced by Erving Goffman ${ }^{5}$ in the sphere of the social sciences, makes reference to the principles of perception that guide individual actions and organize everyday experiences. In this regard, they represent a series of mental orientations that allow individuals to interpret significant social events. Several authors have applied Goffman's contributions in the studies of social movements to schemas of interpretation defined by the way they guide and organize experience. ${ }^{6}$ In this regard, frame analysis has been utilized by different researchers who study religious movements to refer to "the reproduction of systematically transformed situations," that modify the previous schemas of understanding. ${ }^{6}$

On the other hand, sociologist Maurice Halbwachs ${ }^{7}$ from the Durkheimian school introduced the idea of social frames to discuss collective memory. By establishing a connection between individual and collective memory, Halbwachs proposed that the group and society are the conditions, the social frames of memory. The notion of "trend of thought" was added to the concept of collective memory; trend of thought relates to a specific group and thus both of these notions frame the groups in question. In this regard, Halbwachs emphasizes the importance of the interests of the present and the social conditions that enable the awareness of each one. Another sociologist, Michael Pollak ${ }^{8}$ also returns to the issues addressed by Halbwachs and contributes by introducing the notion of conflict to the remembrances of the past in the present. Within this framework, Pollak has dedicated a good part of his studies to human experiences in extreme situations and to memory, taking two very different situations as the basis for his work: the Nazi genocide, on the one hand, and the AIDS epidemic on the other. His works have served as a model for studying memories in the Southern Cone, memories marred by political violence and state repression during military dictatorships. The author suggests that memory is closely tied to one's sense of identity; here memory is understood as a collective operation that attempts to define and reinforce feelings of belonging and social borders.

Each way a social group has of interpreting the past and the present can be understood, according to Pollak, as a process of constructing collective memory. This is the political memory of a group which, through efforts of framing and maintenance, gives each member the feeling of unity, coherence and continuity. In this way, memory becomes a foundational element of identity. Within this framework, Elizabeth Jelin ${ }^{11}$ notes how the individual, in order to establish parameters of identity, selects certain milestones that position him or her in relation to others; these parameters constitute the social frames for positioning memories. ${ }^{11}$ The author also emphasizes the fact that these interpretations and memories of the recent past appear in contexts of political struggles about the meaning of not only what occurred but of the memory itself. In this way, the space of memory becomes a space of political struggle that can be understood in terms of the struggles of "memory against memory,".

All of these works provide insight for thinking about the way relatives signify death based on how they give meaning to the past and identify themselves within a group. In keeping with these studies, we will speak here of interpretative symbolic frameworks in order to emphasize the way in which family members understand the past and present. This is a way of interpreting reality, part of a general cultural context in which "ways of remembering" are articulated with processes of appropriation and reworking of historically constructed symbols and metaphors. Thus the "memories," political actions, social rituals, death rites, public and household practices nourish one another 
and are represented through symbols that allow family members to take action and mobilize.

Within this conception of death framed in historic processes and particular symbolic models, the group is a community of peers that have gone through similar experiences. As such, it plays a fundamental role by giving its members tools to confront losses while also providing a strong sense of identity and social integration. ${ }^{10}$ Like self-help groups in which individuals depend on one another to get through stressful or traumatic experiences based on a shared problem such as illness, addiction, social stigma, etc. Familiares de Malvinas feel understood within their institution by others who lost a loved one in the war. Yet what distinguishes Familiares from the self-help groups is that memory and the group ideology appear as essential components because the issues surrounding the war are reworked according to certain parameters of group identity that respond to the group's specific projects. Thus the integration of the individual to the group has allowed for a process of homogenization that creates a group identity, neutralizes personal differences and permits a common narrative and understanding of death in the war.

The representations that are generated in this interpretative framework respond to representations, values and practices structured at the national level. Many of these cultural configurations like the category of hero or national decorations become cultural tools that express and stage a diversity of meanings through which relatives understand how they relate not only to their dead but also to cultural history. The symbolic frameworks of the group, then, are symbolic repertoires that guide the practices and attributions of meaning of family members to respond to the question of death according to the interests of the groups. It is through these models that family members symbolize a specific type of relationship with their loved ones and identify with one another as members of a certain social group. In this regard, the analysis of death rites or other practices associated with death allow us to understand how Familiares symbolize these extreme experiences. These practices are thus understood not only as instances of bidding farewell, separating from and integrating the social subjects (both alive and dead) but also as expressive methods for communication and reflection that reveal the social framework which allows individuals to give meaning to the past and present and identify themselves within a group.

\section{Familiares de caídos en la guerra de malvinas e islas del atlántico sur}

Familiares de Caídos en la Guerra de Malvinas e Islas Del Atlántico Surwas founded as a commission in 1982 with the goal of generating social spaces where family members could publically pay homage to their loved ones. In this regard, the family members considered it appropriate to radically separate the war from the human rights violations that took place under the dictatorship. In this way, by making reference to the country's official heroic mythology, the group emphasized "Argentinity" as the concept that grouped a nation unified by its Catholic values, beliefs and religious practices, which families understood as traditional characteristics of the Argentine people. The man who played perhaps the most important role in constructing the meaning which the group attributed to death during war was the president of the commission for 27 years, Héctor Cisneros, a brother

${ }^{10}$ Michael Pollak (2006) and Elizabeth Jelin (2002) both emphasize the importance of integrating individuals who have gone through traumatic experiences in peer communities, where feelings of identity, continuity and unity are reinforced. to Mario "el Perro" Cisneros, a professional military man who lost his life during the war. ${ }^{11}$ The following text by Cisneros emphasizes the appeal to the homeland, civic duty and allegiance to the flag, sacrifice and Catholicism as adequate ways to understand and interpret the deaths of the Argentine soldiers: Masses are a regular thing for us and we are on the right path. We cling to God, the Virgin, memory, honor, dignity, the manliness of good, commitment... For us, this has a highly important meaning because it is an act of faith. This is something we have been doing for years; we remember them every day, every day we put in our grain of sand, doing things so that we Argentines won't wipe away what they wrote in blood. Everything time I go down there, I go into the Cathedral and I thank the Virgin and this powerful God of ours. Without hatred, without resentment, we don't hate the British. I go in there and pray, I say some prayers for our boys who died. In this way, to encourage the glorification of the fallen soldiers by society, Familiares de Malvinas ${ }^{12}$ presents their loved ones who died in the war as patriotic heroes through a process of nationalizing both the deaths and the cause of recovering the Malvinas.

Within the symbolic framework of Argentine history, that is, the national and religious symbols and the figures of the founding fathers, which are associated with the unification of cultural diversity, Familiares de Malvinas focus on allegiance to the flag, re-appropriate the image of the Virgen de Luján, and identify their family members with the national heroes consecrated in the country's official history. Similarly, while victimization and the violation of human rights are associated with the disappearance of people in other depictions of the country's recent history, the elaboration of meaning through deaths at war, though also framed in the context of the last military dictatorship, rested not on social protest but on the idea of national unity. In this way, by emphasizing the figure of the hero instead of the victim, Familiares de Malvinas attempts to disengage from the war of state terrorism and propose instead to include those who died at war within the pantheon of renowned national citizens.

With the idea that those who died bled on a land that belongs to all Argentines, for a national cause, the family members utilize an organic metaphor to present the nation as a moral community that goes far beyond its rulers. The symbolic association of body-nation, present in the representations of all the relatives, legitimizes the incorporation of the dead Malvinas soldiers to the lineage of illustrious Argentines. ${ }^{1,2}$ Given, then, that their loved ones gave their lives for the country and were consecrated by the Argentine government as national heroes through Law 24950,,$^{13}$ one of the principal goals of Familiares de Malvinasis to preserve the memory of the fallen as national heroes and promote a social attitude associated with publically honoring these heroes, as occurs with the illustrious dead who preceded them. ${ }^{14}$

The category of hero in these cases refers to lives tragically interrupted for a national cause and is thus considered deserving of a particular type of social recognition. As noted by Santiago Álvarez. ${ }^{12}$

${ }^{11}$ Héctor Cisneros resigned from his post in March 2010 after the Argentine newspaper Crítica published an article revealing that his name appeared on a list of members of Battalion 601, the army's intelligence organization during the dictatorship. The article claimed that Cisneros had been an information analyst at the espionage headquarters under military rule.

${ }^{12}$ From here on, I will use the term Familiares de Malvinas to refer to the Familiares de Caídos en la Guerra de Malvinas e Islas del Atlántico Sur.

${ }^{13}$ Passed on April 3, 1998, Law 24950 declares all Argentines who died defending the country's sovereignty over the South Atlantic Islands in the 1982 conflict as national heroes.

${ }^{14}$ For a more in-depth examination of the social attitude associated with honoring illustrious Argentines of the past, see Sandra Gayol (2010). 
when violent deaths are viewed as altruistic, they can elevate the person to the category of hero. ${ }^{12}$ In this case, for the family members the heroic act implies a sacrifice for the country and ideal values that are associated with responsibility and moral obligation; these are related, among other things, with the idea of keeping one's word. ${ }^{13}$ In this way, many family members emphasize the fact that the fallen kept their word after swearing their allegiance to the flag during their military service.

The sacrificial act is what sets an individual apart in the native category of national hero. From the narratives of family members, specifically in cases in which mothers emphasize their resistance to letting their sons go to war, I can interpret that their sons' decision to fight and die make them both victims and sacrifices, since they offer their lives to consecrate their country. Although these are the same family members who refer to the experience of heroes as a sacrificial act, the contributions of Henri Hubert and Marcel Mauss ${ }^{14}$ on the nature of sacrifice are relevant here. According to the authors, in every sacrifice the object passes from the common to the religious domain since it is consecrated; it also modifies the condition of the moral person who accomplishes it or that of certain objects with which he is concerned..$^{14}$ In this way, we are speaking as much about what the authors refer to as personal sacrifices as well as objective sacrifices. In the first case, the sacrifice directly concerns the person making the sacrifice; in the second, the principal effect is obtained by the target which the rite aims to modify. In the case of the Familiares de Malvinas heroes, I will refer to them as voluntary sacrifices since, as I have noted, they perform the sacrifice and are also its victim.

This meaning given to death as a special case of sacrifice is characteristic of the members of the commission, setting them apart from other family members who opted not to join the group. These relatives, although they acknowledge the need for social recognition of the deaths that occurred during the war, do not signify the deaths as a sacrifice for the homeland. Our research found that beyond their objectives of publically honoring the dead, the family members sought from the beginning to establish a specific relationship with their loved ones, as I will examine below.

\section{La virgen de luján}

Familiares de Malvinas use a symbol with a strong Argentine identity, la Virgen de Luján, to consecrate the fallen Malvinas soldiers as national heroes. Chosen by the Church as one of the pillars of the Christianization of the State, the virgin was chosen as Argentina's patron saint in 1930. A figure of the virgin was donated to the commission by the bishopric located in Mercedes (province of Province Aires) in 2002. Also the patron saint of the army, she is identified with traditional Catholicism, country symbols and Argentine national identity. The history of how the Argentine army came to worship this particular virgin dates back to the times of General San Martín and General Manuel Belgrano (Martín, 2002). In addition, members of the military religious services of the different branches of the armed forces of Argentina have promoted the worship of this virgin since their founding. ${ }^{15-17}$ In this regard, it is useful to note that a statue of the Virgen de Luján made a special appearance in the Malvinas War. On May 8, 1982, the day of the "Feast of Our Lady," Chaplain Vicente Martínez Torrens led a mass in honor of the Virgin for the RI Mec 25 (an infantry regiment that had participated in the attempt to recover the islands on April 2, 1982). After the mass, there was a procession headed by a statue of the virgin that made its way along the armed forces' lines of defense. ${ }^{18}$ In addition, on June 11, 1982, as the Malvinas War continued, Pope John Paul II visited Argentina and prayed before the original image of the Virgen de Luján at the Luján Basilica to celebrate the peace accord in the conflict between Argentina and Great Britain and entrusting the virgin with the future relations among the two countries. ${ }^{15,16}$

Thus Familiares de Malvinas utilizes an icon with a national Catholic identity, a figure highly worshipped among the people due to the miracles attributed to her ever since her arrival in Argentina. In addition, she played a special role in the $\operatorname{war}^{16}$ and helped recover the symbolic capital of the heroes, a capital which had been devalued due to the undermining of both State and society. In addition to having been incorporated to almost all the activities organized by the commission, the image of the Virgin was also taken to nearly every province as part of the organization's pilgrimages. Members of the Familiares de Malvinas commission participated in these pilgrimages and the main goal was to use the Virgin to take the memory of war to different parts of the country. The Virgin would receive the prayers and offerings of all the Argentines before October 10, 2009, the day in which she was taken to Darwin cemetery, next to the Monument to the Fallen on Isla Soledad.

During the pilgrimages, Argentines from across the country left offerings to the Virgin before she departed for the islands. Among the many requests, some asked her to look after the country's heroes. It's just amazing, the requests, all the things that go on. But not just in Buenos Aires, everywhere, from La Quiaca to the Southern Patagonian Ice Field. It's about giving something that belongs to you to the virgin in exchange for her doing you a favor; it's about her being there for them, looking after them, loving them. (Delmira de Cao, September $3,2009)$ I accompanied the virgin for 70,000 kilometers. I went along with her because everywhere she went; she went to see one of her sons, one of the dead veterans. And if she goes to Malvinas, well then she'll be looking after the boys who are there. (Paula Cardoso, June 3, 2009) The symbolic and material act of worshippers who prayed and made offerings to the virgin had several goals, as can be seen in these comments. On the one hand, worshipping the virgin is considered synonymous with worshipping the dead, since through her figure; offerings are being made to the fallen: The virgin doesn't just take our prayers and blessings for the heroes she also carries souvenirs, rosaries, rings and letters. Boxes and boxes of them. There were people who left their wedding rings. (María Fernanda, October 9, 2009).

The virgin, who represents the symbolic body of the nation in this case, thus carries the memory of the war and its heroes to different towns across Argentina. On the other hand, this worship is understood as a sort of compensation in exchange for the spiritual care she will provide the heroes on the islands. Thus, through the offerings and prayers of Argentines from across the country, she will take them with her to the final resting place of the dead soldiers. Finally, through the idea of the virgin as a protective mother, the Malvinas mothers extend

${ }^{15}$ In spite of the fact that the Virgen de Luján played an important role in the Malvinas War, she is not seen by family members as an icon of the war since they do not understand or justify the struggle. In this regard, as we will see below, they view the Virgen de Luján as a national symbol who has accompanied them as well as their fallen family members and as a figure who looks after the dead. Thus, she is also presented as a symbol through which relatives find a particular way of being in touch with their loved ones.

${ }^{16}$ For more on the Virgen de Luján as a symbol of national Catholic identity in Argentina and a detailed examination of her worship, see Eloísa Martín (2000) and Patricia Fogelman (2003). 
their maternal love and bonds bonds interrupted by the war and also obstructed after death, due to the absence of the bodies or distance to the spot where they were buried: She's the mother I couldn't be, the mother that so many women who lost their sons couldn't be. She's the mother who is going to keep them safe, surround them and be there for them spiritually. That is the virgin's mission. And she takes the message and the recognition of the entire Argentine people (Delmira de Cao, September 3, 2009).

It is important to note, in this regard, that only certain family members (among them, some quoted here) consider the virgin a mediator, a medium for communion among Argentines. ${ }^{17}$ I would like to emphasize that not all relatives of fallen soldiers (and certainly not all Argentines) attribute this role to the virgin, and in this article, she is similarly not considered a religious icon that connotes Argentina's national identity. As in the pilgrimages analyzed by Turner, ${ }^{19}$ both those who make the journey with the virgin (the relatives) as well as the people they visit along the way participate, as "Argentines", in the experience of communitas, ${ }^{18}$ whose sense of communion is produced in the divine manifestation that is experienced through her movement from place to place. Similarly, the ritual subjects undergo a transforming experience through their connection with the sacred order. ${ }^{19}$ However, unlike the usual Catholic pilgrimages in which people visit a sacred center, in this pilgrimage the destination is not a sanctuary but different towns; the virgin, then, is the center of the worship, a pilgrim herself. In this inversion of the characteristics of the rite, where the symbol of the sacred center is the means towards an end, the experience of the pilgrimage is not limited to the towns but extended to the family members and to the virgin, who is the gatherer and distributor of Argentinity. Thus the Malvinas are territorialized within the Argentine mainland and the virgin feeds off of the country's geographical and cultural diversity to territorialize the lost islands with the Argentine mainland. In this double process of territorialization, the national identities of the families, the people of the towns, the heroes and the islands are strengthened.

On the other hand, in this transformative experience of the ritual, the relatives recover the symbolic power they have inherited from their sons, which has been darkened by the desmalvinización after the war, a process they have understood as denationalization, silence and society's lack of awareness of the Malvinas War. Thus, with the statue of the virgin circulating through the provinces, the relatives position themselves spatially and socially around a sacred symbol par excellence to express their demand for both their own social recognition and that of their heroes. Thus, the figure of the virgin serves as a framework for reinforcing the sacred nature of their heroes/those who died for their country, to quote Guber, within the "country's honorable events,". ${ }^{20}$

For this reason, in this process of symbolic re-signification that occurs during the pilgrimage, homage is rendered to the dead through the Virgin, with the offerings and the practice of worship, and national identity is reinforced. The Virgen de Luján has also played a fundamental role in the masses held annually in honor of the soldiers who died at war on April 2nd at the Catedral Metropolitana. At these ceremonies, ${ }^{19}$ the bishops entrusted with the mass emphasize society's

${ }^{17}$ This mediation between the sacred and the profane and between the living and the dead through the saints can be found in both official Catholicism as well as popular religious manifestations.

${ }^{18}$ Turner understands communitas as a generic bond either devoid of structure or interstructural given there are no names, roles or categories that denote social differences. It occurs during the liminal period described above (1998:103).

${ }^{19}$ The descriptions of these masses are the synthesis of four consecutive years of fieldwork. duty to honor those who died for their country and defend those who returned from the war. These masses are attended by family members of the soldiers as well as veterans, active military, friends of the family and a general public. Before each mass begins, a veteran who collaborates with Familiares de Malvinas reads a commemoration and the image of the Virgen de Luján is carried up to the altar by other veterans. Once the mass is over, the relatives carry out a funeral procession, taking flowers in an offering to the virgin and to the fallen (649 red rose buds that represent the dead): The mass we hold in the cathedral on April 2nd is just wonderful. It is the only ceremony we do and we bring a huge flower arrangement that we leave at the altar. For us, these flowers represent the 649 men who died. Since 2002, the year in which Familiares de Malvinas received the Virgin, until 2009, the year in which she was left at the Darwin cemetery, the bishops blessed the image of the virgin every year on April 2nd. The virgin thus played a fundamental role at all the ceremonies, where she was placed at the foot of the altar. This allows us to view the figure of the virgin as a dominant symbol since in the practices that take place when she is present in both the pilgrimages and the other activities both death and the surviving family are addressed by the other participants in the ritual. In this way, at the end of each mass, the relatives cry and embrace one another in the presence of friends and others. This is exactly what occurs in other funeral rites, where the family members and the deceased are the focus of the attention. The pain of losing a loved one, then, is staged. Before the official inauguration at Darwin cemetery, which did not take place until October of 2009, then, the ceremonies held on April 12th at the Cathedral, in the presence of the Virgin, served as annual reenactments of the wakes and the funerals held before the burials, where the subjects move from the living to the dead. The Virgin thus mediated between the family members and the dead in these masses.

In 2009, the Virgin was established and the dead were consecrated as national heroes through the ritual of inaugurating the monument. This is the point where when we can say that the means, in the absence of the Virgin, became the rite of commemoration whose only role was to connect the relatives with the memory of the deceased. As we have noted, the statue of the Virgen de Luján, as established in Darwin cemetery on Isla Soledad, played a fundamental role in inaugurating the cenotaph in an act that Familiares de Malvinas fought for during nearly a decade and a half, an act that finally took place at the cemetery in 2004. The ceremony was funded by the State and organized, through the mediation of the commission, by the Argentine Foreign Ministry. Thus, one of the most important achievements of the commission was the construction of the monument, which was donated by the entrepreneur Eduardo Eurnekian and whose main goal was to create a symbolic space where the dead could receive offerings at the place where they had lost their lives and their bodies had disappeared. The construction of the monument in Darwin cemetery appears as a singular event in the history of war confrontations in that it belongs to the defeated but is administered by the conqueror. In this way, through an Argentine monument and the presence of the deceased, two different ways of legitimizing and exercising sovereignty come together: that of the Argentines and the British. While in the latter, the occupation is a reminder of the victory of the British forces, the former is understood as symbolic and spiritual. Thus, the family members refer to the cemetery as "the only permanent presence of the Argentines on our islands in the post-war period." ${ }^{20}$

The project of the trip to inaugurate the monument begins to be

${ }^{20}$ Comisiónde Familiares de Caídosen MalvinaseIslasdel Atlántico Sur, at http://www.noretornable.com.ar/v2/dossier/carta.html 
planned when its construction is completed in April 2004. After a series of negotiations with the British embassy, an agreement was made to supplement the only weekly flight scheduled to the islands each Saturday. ${ }^{21}$ After these negotiations, two flights were scheduled, on October 3 and 10,2009. The logistics of the journey were left to Familiares de Malvinas, both on the mainland and on the islands, in order for all the interested parties to make the trip. Some family members travelled through several provinces with personnel from the White Helmets in order to contact veterans and the family members of the deceased in each location. On the islands, other relatives ensured that the cemetery was ready to welcome them. Since they would only enjoy a brief stay, they travelled one day before the schedule trip to ensure that there was a flower on every tomb, placing 649 flowers in the cemetery among the 320 crosses and the large cross. As part of the activities organized by the commission, the physical presence of the virgin played a key role in the cemetery alongside the dead. "We made sure the virgin looked beautiful... and then we added the sun... No one even realized it but she had a decorated sun, all golden with those little white things."

Before travelling to the islands, both groups came together at the Bauen Hotel in the city of Buenos Aires. During the first trip, while the first group was on the islands, other family members went on a procession to Luján with the statue of the virgin and later, the day before the second trip, they marched with her from the hotel to the cathedral to bid her farewell. The family members had to travel by bus to Río Gallegos, where they would take the plane to Malvinas. Once on the islands, another vehicle took them to the cemetery, where the commission had already handled the details, organizing the ceremony and making sure everyone had what they needed. While it was the Argentines who prepared the cemetery and organized the event, the British hosts of the ritual put up tents with food and beverages for the relatives. ${ }^{22}$ This sphere of the ritual is again indicative of the coexistence of two types of sovereignties, the Argentine and the British, with the United Kingdom reaffirming its authority over the territory by serving as host. Thus, a practice of reaffirming sovereignty and legitimizing authority can be seen. The dead become political victims, the bodies become country symbols, and the relatives and hosts become agents at odds with one another. At the same time, the ritual, where multiple meanings which vary among the participants overlap, is both political and a rite of death, where the social positions of the relatives and the dead are not the only public affirmation: so are the political aims of the dead and the legitimation of the domain of the hosts. ${ }^{23}$

${ }^{21}$ The flights to the islands from Argentina cannot be made by an Argent airline and thus the only option is a Chilean airline. Since the last Join Declaration by Argentina and the United Kingdom, these civilian flights depart from Punta Arenas to the Malvinas Islands, making a stop in Río Gallegos.

${ }^{22}$ British authorities and military attended the ceremonies held on October $3^{\text {rd }}$ and $10^{\text {th }}$.

${ }^{23}$ Within this framework of disputed sovereignty, we can understand what occurred at the Darwin cemetery when the image of the Virgen de Luján was recently attacked. The attacked was never identified and the act is seen by the Familiares commission as a desecration of the monument to the fallen, one that is framed within a series of hostile acts by certain British sectors (see http:// www.heroesdemalvinas.org.ar/museodeheroes/). Since this attack took place a year after I had finished my research on the experience of family members of the soldiers who died in Malvinas, it is not analyzed in this work. However, I believe it is important to be aware of this incident and keep it in mind for future research. On the one hand, I want to emphasize that in academic literature on the Malvinas War from the British experience, I did not find any works that focus on the experience of British relatives and their method for confronting the death of their loved ones during the war. In this regard, it would be interesting to do a comparative analysis of the experiences of family members on both sides of the conflict, keeping in mind that many news articles make reference to the use of poppy flowers as a symbol of memory, the construction
To return to the celebration of the ritual on Isla Soledad, before the priests led the masses, the families had their own private time to find the cross of their relative or their name on the cenotaph. In the ceremony of the second journey, whose members were entrusted with leaving the virgin in the cemetery, a mass was led by a Catholic priest while the family members came over to greet, bid farewell and make their offerings to the virgin and to the dead, leaving their belongings in a transparent urn: So when the virgin came in, they got up from their chairs, they went over to have a moment with the virgin. They sang, they accompanied her to the altar, they all did everything. They participated in the religious service, they went to say goodbye to the virgin, they went to say goodbye to their deceased boys, all in peace and serenity. And there was the virgin; they brought her in a pickup truck. All the people went over there and the virgin arrived. She was on a pedestal. That's when they held the mass and the people, they cried, everyone was crying. Everyone, it was very moving. I was wearing these gold earrings, and let me tell you how moved I was: I took the earrings, I put them into an envelope that was in my purse and I dropped them in, and then people threw flowers. Just then it hit me that I had thrown in my gold earrings. It was very moving, a very intense moment. It's just something that I, well I said, "I left my earrings in the urn there on Darwin." Because by doing so, I was making an offering to my son. In addition to this last contact with the virgin, the visit to the cemetery gave the family members the chance of actually touching the land where their relatives had died and paying homage to them at the spot where their bodies lay.

In reference to the social processes that an individual goes through when changing his or her status or social position, Van Gennep ${ }^{21}$ proposes the model of the rite of passage, which is divided into phases of separation, transition and incorporation. As a rite of death, the official inauguration of the cemetery and the enthronement of the virgin served for many family members as the incorporation phase of the rite of death. In this closing of the rite, the living relatives definitively separate from their dead; the dead are incorporated to the world of the dead; and the living is reinserted as relatives of the dead into society. Returning to Van Gennep's ${ }^{21}$ work on rites of passage, Pierre Bourdieu proposes the termrites of consecration or rites of legitimation, emphasizing the separation that is produced between those who have undergone it and those who will never undergo it. The essential function of the rite is, according to Bourdieu, to institute "a lasting difference between those to whom the rite pertains and those to whom it does not pertain,". ${ }^{21}$ When referring to the way in which rites of consecration "solemnly mark the passage over a line which establishes a fundamental division in the social order." the author emphasizes that it is more important to emphasize the dividing line than it is to focus attention on the rite of passage itself. It is interesting to think about these terms in order to again reflect on the position adopted by many family members who decided not to dig up and identify or bring back to the Argentine mainland the remains of family members buried at Darwin. ${ }^{24}$ Among the reasons given by Familiares, the most

of cenotaphs and other ritual practices aimed at honoring the dead. (See http://www.bbc.co.uk/newsround/15492752http://www.orihuelacostarbl.com/ Falklands\%20War\%20memorial\%20 and etum.html,http://www.metro.co.uk/ news/78862-

${ }^{24}$ The possibility of unearthing the bodies for future identification is a topic that, according to some informants, was actually proposed by the British, who made several attempts at "repatriating" the bodies to the Argentine mainland. Beyond these British initiatives, many veterans and relatives who were not part of the Familiares organization requested the disinterment in order to identify the dead. Familiares members interpret this attempt as a British policy of wanting to get their boys out of Malvinas, that is, to free the disputed terrain of Argentine bodies and they stoutly refuse to have the bodies unearthed and identified. For more on this topic, see Panizo. ${ }^{22}$ 
prevalent one is that the deceased are making homeland: "They are there, right there, and they fought to be there. You get it? So they have to stay there, making homeland. Because those are Argentine flags that demand we be recognized,"

Since the war was lost, in order for the sacrifice not to be viewed as futile from this point of view, it is critical that the contractual exchange implied in the notion of "sacrifice" involve a certain sovereignty over the islands through the bodies laid to rest in the cemetery. During and after the war, the islands came to occupy a primordial place on the symbolic map of family members. The transformation of these islands into sacred lands can be seen in the metaphoric language of the relatives, who position the Virgin, the body of the heroes and the land for which they fought within the same semantic field. Thus, through the idea of voluntary sacrifice and the organic metaphor that associates the body and the "spilled blood" with the land, the dead are understood as a metonym for the land. In this symbolic equation, the relatives come to understand the dead as if they were national means for producing sovereignty.

In this regard, the official inauguration of the monument can be understood as the closure of the sacrificial rite in which the sacrificed object undergoes a sort of official consecration as the sacred heroes and protectors of the homeland. Similarly, it is important to emphasize that since joining the commission, many of the family members have spent their lives vindicating their sons' struggle to recover Argentina's territory. As part of this dedication, they have sacrificed the dead by renouncing their right to reclaim their bodies (just as the heroes have sacrificed their lives) in order to exercise sovereignty over the territory. A specific relationship is thus established between the dead and the disputed land, a relationship that generates, as I mentioned earlier, an ontological transformation of both the bodies and the land. This can explain why after the ceremony on the islands, the commission handed out little bags of soil for the family members to take home with them. In a similar gesture, many veterans and relatives took with them Virgen de Luján miniatures in order to cover them and mix them with the same sacred soil where the dead are buried.

Thus, de Cao's metaphor of the bodies "Argentine flags that demand we be recognized," is significant since it makes the bodies into symbols that consolidate the families' projects for sovereignty. Here the families understand their dead as not just any dead but as national heroes that, in native words, "entered the history of the great," and as such, "must continue to stand guard for Argentina." This last phase of the rite of passage in death rites, the integration of the dead into the world of the dead and the return of the living to their world, requires a definitive separation between the participants of the rite (the deceased and their families). In this case, this occurs in terms of the sanctified and the not sanctified. Here the deceased do not move into the world of the "common" dead but into the world of "dead heroes," as occurred with other Argentine forefathers. However, what distinguishes those fallen in Malvinas from other heroes is the location of their bodies, which metaphorically represent Argentina sovereignty over the islands. In this way, the families are able to make their definitive separation from the dead, who are integrated into a symbolically dense geographical space where they will be consecrated in a special category of the dead, with the sacred intermediation of the Catholic symbol of Argentinity par excellence (la Virgen de Luján). At the same time, the effect of the rite also acts on the earth since, as noted earlier, it becomes Argentine through both the dead citizens as well as the Virgin.

Thus, in this radical separation between the living who will never go through this kind of rite of passage, and the dead, who are consecrated through the rite by which they become the heroes and protectors of the homeland, the spatial location of the bodies and of the virgin becomes fundamental. The cemetery is the border between the profane and the sacred while joining, as we have seen, the islands with the rest of Argentina's territory through the virgin and the deceased. In the words of Bourdieu, the most important effect of the rite, in this case, the culmination of a sacrificial rite, lies in consecrating difference, separating the patriotic and sacred hero from other mortals who are "not subject to this ritual operation," (1992:115). The symbolic power of the bodies in Darwin cemetery, then, extends beyond the level of sovereignty over the disputed territory to the consecration of the ritual subjects as predestined to fight and die for this cause. Thus Familiares de Malvinas constructs its national identity through the heroes, the islands and the Virgen de Luján.

The inauguration of the monument at Darwin in the presence of the Virgen de Luján as the protective mother of the homeland and of the dead did not only enables the existential transformation of the ritual subjects but also materialized the way in which family members, through their dead soldiers, construct their representations of national belonging.

\section{Discussion}

In this article I observe the way in which relatives give meaning to losses that occur as part of national events. In this regard, death at war is understood as a citizen's act of national sovereignty that includes the exemplary values of altruism, social responsibility and voluntary sacrifice. On the other hand, we saw how through the organic metaphor of the Malvinas earth being watered by the blood of the dead, the family members symbolize their relationship to their deceased and the relationship between the deceased, the islands and the nation. Similarly, the article examines the figure of the Virgen de Luján, a sacred source of legitimation among the dead and their relatives, to see how for relatives, she becomes a tool for the communion of all Argentines, both living and dead, and reinforces the national identity. Thus losses are dealt with through a process of nationalizing the dead, allowing the dead bodies to exercise a sort of symbolic sovereignty over the islands, a territorial conquest in spite of Argentina's defeat at war. $^{23-28}$

\section{Acknowledgements}

None.

\section{Conflict of interest}

Author declares that there is no conflict of interest.

\section{References}

1. Rosana G. Por qué Malvinas? De la causa nacional a la guerra absurda. Fondo de Cultura Económica. Spain; 2001.

2. Federico L. Las guerras por Malvinas. Edhasa. Spain; 2006.

3. Elizabeth J. Los derechos humanos y la memoria de la violencia política y la represión: la construcción de un campo nuevo en las ciencias sociales. Cuadernos del IDES no 2. 2003.

4. Rosana G. Crucero ARA General Belgrano in memoriam. Linajes políticonavales en las memorias de Malvinas. Iberoamericana. 2008;30(1):7-27.

5. Erving G. Frame análisis: An essay on the organization of experience. Harper Colophon Books. USA; 1974. 
6. Julia CM. El concepto de marco interpretativo en el estudio de movimientos religiosos. Sociedad y Religión. 1998;16/17:33-51.

7. Maurice H. Memoria individual y memoria colectiva. Estudios. 2005;16:163-187.

8. Pollak M. Memoria, olvido, silencio. La Plata. Argentina; 2006. p. 113.

9. Clifford C. La interpretación de las culturas. Gedisa. Spain; 1997. p. 375.

10. Víctor T. La selva de los símbolos. Siglo 21. Spain; 1997.

11. Elizabeth J. Los trabajos de la memoria. Siglo 21. 2002.

12. Santiago A. Enterrando heróis, patriarcas, suicidas e traidores: solidariedade e ostracismo nos andes colombianos. MANA 2001;7(2):35-55.

13. Julian P. Antropología del Honor. Spain; 1979.

14. Henri H, Marcel M. Magia y sacrificio en la historia de las religiones. Lautaro. Spain; 1949.

15. Eloisa M. La construcción de Aparecida y Luján como Patronas nacionales: un análisis comparativo. Estudios sobre Religión 9. 2000.

16. Martín O. La Iglesia católica durante la guerra del Atlántico Sur. Revista Cuadernos Argentina Reciente. 2007;4:1-13.

17. Fernando L. Las dictaduras en Argentina y la clericalización de la legislación. Lidée libre - Revue de la Libre Penseé. 2012. p. 296.

18. Vicente MT. Dios en las trincheras. Archivo Histórico Salesiano de Patagonia. Argentina; 2007.
19. Víctor T. Dramas, fields and metaphors. Symbolic Action in Human Society. Cornell University Press, UK; 1975.

20. Rosana G. De chicos a veteranos. Memorias argentinas de la guerra de Malvinas. Antropofagia. Argentina; 2004. p. 84.

21. Arnold VG. Los ritos de paso. Antropología social y cultural. Spain; 2008.

22. Marina PL. Dónde están nuestros muertos: experiencias rituales de familiares de desaparecidos de la última dictadura militar en la Argentina y caídos en la Guerra de Malvinas. Tesis de Doctorado, Universidad de Buenos Aires, Argentina; 2011.

23. Pierre B. Los ritos como actos de institución. In: Rivers JP, Peristiany JG, editors. Honor y Gracia. Spain; 1993. p. 111-123.

24. Ludmila C. No habrá flores en la Tumba del pasado. La experiencia de reconstrucción del mundo de los familiares de desaparecidos. Mana. 2001;9(1).

25. Patricia F. Reconsideraciones sobre los orígenes del Culto a la Virgen de Luján. Entrepasados. 2003;23:123-148.

26. Sandra G. Los despojos sagrados: funerales de estado, muerte y política en la Argentina del centenario. In: Tato MI, Castro M, editors. Del centenario al peronismo, Dimensiones de la vida política argentina, Argentina; 2010. p. 9-29.

27. Rosana G. Crucero ARA General Belgrano in memoriam. Linajes políticonavales en las memorias de Malvinas. Iberoamericana. 2008;30(1):7-27.

28. Víctor T. El proceso ritual. Taurus; Spain; 1998. 